$\begin{array}{rr}\text { FIT(1)PATOLOGI } & \text { Volume } 13, \text { Nomor 3, Mei 2017 } \\ \text { I N D ONES I A } & \text { Halaman } 81-88 \\ \text { ISSN: } 0215-7950 & \text { DOI: } 10.14692 / \text { jfi.13.3.81 }\end{array}$

\title{
Kemampuan Tumbuhan Terna dalam Menekan Potensi Inokulum Rigidoporus microporus
}

\section{Suppression Ability of Herbaceous Plants on Inoculum Potential of Rigidoporus microporus}

\author{
Sika Yulianti, Suwandi*, Nurhayati \\ Universitas Sriwijaya, Palembang 30662
}

\begin{abstract}
ABSTRAK
Penyakit akar putih yang disebabkan oleh Rigidoporus microporus ialah penyakit penting pada tanaman karet yang sukar dikendalikan. Kemampuan beberapa jenis tumbuhan terna dalam menekan potensi inokulum dan infeksi $R$. microporus diuji pada percobaan dalam pot kantong plastik. Tumbuhan terna yang diuji ialah garut (Marantha arundinacea), temulawak (Curcuma xanthorrhiza), lidah mertua (Sansevieria fasciata), lengkuas hutan (Alpinia malaccensis), lengkuas (A. galanga), ganyong (Canna indica), kunyit (Curcuma longa), talas (Colocasia esculenta), dan uwi (Dioscorea alata). Inokulum patogen yang berupa miselium pada potongan kayu karet dibenamkan selama 90 hari pada tanah yang ditanami tumbuhan uji. Hasil penelitian menunjukkan bahwa pembentukan rizomorf $R$. microporus dalam tanah nyata lebih rendah pada perlakuan garut, temu lawak, lidah mertua, ganyong dan talas. Penekanan viabilitas inokulum dan pertumbuhan rizomorf terjadi pada seluruh perlakuan tumbuhan terna uji, kecuali lidah mertua. Pengamatan lebih lanjut, tidak ditemukan kolonisasi rizomorf dan nekrosis akar tunggang pada bibit karet pada perlakuan tumbuhan terna, kecuali pada perlakuan lengkuas hutan dan lidah mertua
\end{abstract}

Kata Kunci: karet, penyakit akar putih, potensi inokulum, rizomorf

\begin{abstract}
White root disease caused by Rigidoporus microporus is an important disease of rubber tree and is very difficult to control. The ability of some herbaceous plant species to suppress inoculum potential and infection of $R$. microporus was studied in a pot trial. Nine species of herbaceous plants were examined, i.e. arrowroot (Marantha arundinacea), java curcumin (Curcuma xanthorrhiza), sansevieria (Sansevieria fasciata), Mallaca galangal (Alpinia malaccensis), greater galangal (Alpinia galanga), Indian shot (Canna indica), curcumin (Curcuma longa), wild taro (Colocasia esculenta), and water yam (Dioscorea alata). Pathogen's inocula as mycelial colonizing rubber wood sticks were buried for 90 days in soil planted with tested plants. The results showed that formation of $R$. microporus rhizomorph in the soil was lower in pots planted with arrowroot, java cucurmin, sansevieria, Indian shot, and wild taro. All herbaceous plants, except sansevieria, caused suppression of inoculum viability and rhizomorph development. Further observation showed no colonization of rhizomorph nor necrosis of the root was found, except on Mallaca galangal and sansevieria.
\end{abstract}

Key words: inoculum potential, rhizomorph, rubber, white root disease

*Alamat penulis korespondensi: Laboratorium Fitopatologi, Fakultas Pertanian, Universitas Sriwijaya. Jalan Palembang-Prabumulih Km.32 Indralaya, Palembang 30662

Tel: 0711-580663, Faks: 0711-580663, Surel: suwandi@fp.unsri.ac.id 


\section{PENDAHULUAN}

Penyakit akar putih merupakan penyakit penting pada tanaman karet yang disebabkan oleh jamur akar putih (JAP), yaitu Rigidoporus microporus (sinonim Rigidoporus lignosus) (Semangun 2007). Penyakit ini menyerang tanaman karet di berbagai negara terutama daerah tropis seperti Indonesia dan menyebabkan kerugian yang cukup besar. Patogen ini menginfeksi dan menyebabkan pelapukan akar sehingga menyebabkan kematian baik tanaman muda yang belum menghasilkan maupun tanaman yang sudah menghasilkan. Di Indonesia, penyakit akar putih diperkirakan menyebabkan kematian pada tanaman karet di perkebunan antara 3\% dan $5 \%$. Natawijaya (2007) menduga nilai kerugian sekitar Rp300 miliar pertahun untuk perkebunan karet rakyat.

Metode pengendalian penyakit akar putih telah banyak ditemukan, tetapi belum mampu mengatasi masalah penyakit secara efektif dan ekonomis. Membersihkan lahan dari tunggul dan sisa akar dari areal perkebunan secara mekanik efektif menekan penyakit, tetapi belum dapat diadopsi oleh kebanyakan petani karena biaya yang mahal (Natawijaya 2007; Hashim dan Malik 2007). Mikrob antagonis seperti cendawan Trichoderma spp., Paecilomyces lilacinus, dan bakteri Bacillus subtilis dilaporkan dapat secara parsial mengendalikannya (Fairuzah et al. 2014; Kusdiana et al. 2015), tetapi keefektifannya tidak konsisten dan tidak bertahan lama (Suwandi 2008). Tindakan pencegahan berupa pengurangan jumlah inokulum pada tunggul seperti penggunaan bahan kimia untuk meracuni tunggul tua juga kurang efektif (Fox 1977).

Tumbuhan terna diketahui dapat bersifat antagonis atau alelopati terhadap JAP sehingga berpotensi dikembangkan untuk pengendalian hayati. Pengendalian dengan tumbuhan terna mudah diterapkan oleh petani dan murah, bahkan pengendalian bersifat terus-menerus sepanjang tanamannya hidup. Tumbuhan terna yang dilaporkan mampu menekan penyakit akar putih ialah temu lawak (Curcuma xanthorrhiza), lengkuas (Alpinia galanga), kunyit (Curcuma longa), garut (Marantha arundinacea), lidah mertua (Sansevieria fasciata), sigsag (Pedilanthus tithymaloides), cocor bebek (Kalanchoe pinnata), pandan (Pandanus sp.), dan sambiloto (Andrographis paniculata)(Situmorang etal. 2007). Meskipun dilaporkan dapat menekan serangan patogen, tetapi belum diketahui peranan tumbuhan terna dalam pengurangan potensi inokulum patogen.

Potensi inokulum merupakan energi pertumbuhan yang tersedia bagi patogen untuk menginfeksi inang. Potensi inokulum $R$. microporus bergantung dari ukuran alas makanan, yaitu kayu yang dikoloni oleh miselium yang hidup (Liyanage et al 1980). Pada penelitian ini potensi inokulum diduga berdasarkan kemampuan pembentukan rizomorf dalam tanah, viabilitas inokulum, kecepatan pertumbuhan rizomorf, panjang keseluruhan rizomorf dan pelapukan kayu inokulum. Penelitian ini mengevaluasi potensi tumbuhan golongan terna dalam penekanan potensi inokulum patogen dan dampaknya pada bibit karet.

\section{BAHAN DAN METODE}

Penelitian disusun dengan rancangan acak kelompok menggunakan 10 perlakuan dan 4 ulangan. Perlakuan terdiri atas 9 jenis tumbuhan terna dan tanpa tumbuhan terna (kontrol). Tumbuhan terna yang diuji ialah temu lawak, lengkuas, kunyit, garut, lidah mertua, lengkuas hutan (Alpinia malaccensis), ganyong (Canna indica), talas (Colocasia esculenta), dan uwi (Dioscorea alata).

\section{Penanaman Tumbuhan Uji}

Tumbuhan uji (tanaman karet dan tumbuhan terna) diperoleh dari kebun karet atau tanaman pekarangan di Kabupaten Penukal Abab Lematang Ilir (PALI), Sumatera Selatan. Bibit terna yang digunakan ialah akar rimpang, umbi atau anakan yang bertunas. Bibit karet uji yang digunakan ialah bibit asal biji sapuan dengan diameter pangkal batang 4-5 mm. Bagian ujung batang dipotong sepanjang $15 \mathrm{~cm}$ dari pangkal batang dan 
bagian ujung akar tunggang dipotong sehingga menyisakan akar tunggang sepanjang $15 \mathrm{~cm}$. Akar lateral dibersihkan sehingga diperoleh bibit yang berupa stump karet (Suwandi 2008). Tumbuhan uji ditanam pada tanah yang diambil dari kebun karet yang terinfeksi $R$. microporus. Uji menggunakan pot kantong plastik transparan ukuran $1 \mathrm{~kg}$ (untuk mempermudah pengamatan pembentukan rizomorf dalam tanah), kemudian dimasukkan ke dalam kantong plastik hitam. Setiap pot kantong plastik ditanam satu bibit terna dan dua bibit karet. Pot ini diletakkan di kebun percobaan di bawah naungan 50\%. Selanjutnya tumbuhan uji dipelihara dengan penyiraman dan penyiangan gulma, tetapi tidak dilakukan pemupukan.

\section{Penyiapan Inokulum}

Inokulum $R$. microporus diperoleh dari akar tanaman karet yang sakit dari satu kebun karet di PALI, yaitu tanaman karet yang telah mati, lapuk dan bagian kulit akarnya dikoloni oleh rizomorf $R$. microporus dan bagian kayu mengalami pelapukan. Akar tanaman sakit dipotong-potong sehingga dihasilkan inokulum berbentuk potongan kayu dengan ukuran $5 \mathrm{~cm} \times 0.5 \mathrm{~cm} \times 0.5 \mathrm{~cm}$. Jumlah potongan kayu inokulum JAP yang disiapkan ialah sebanyak 1760 buah. Pertumbuhan miselium atau rizomorf $R$. microporus pada potongan kayu terlebih dahulu dipicu dengan cara dimasukkan dalam kantong plastik transparan berklip, ditambahkan air secukupnya (kelebihan air dibuang dengan cara menekan kantong plastik sehingga seperti menjadi hampa udara), kemudian diinkubasi ditempat gelap selama 7 hari (Suwandi 2008). Potongan kayu yang bermiselium selanjutnya ditanam dalam tanah di sekeliling tumbuhan uji pada jarak $5 \mathrm{~cm}$, dan setiap tumbuhan uji ditanam 10 buah inokulum.

\section{Pembentukan Rizomorf dalam Tanah}

Rizomorf yang terbentuk dalam tanah pada sisi kantong plastik diamati pada 45 dan 90 hari setelah pembenaman. Persentase pembentukan rizomorf (PPR) dihitung menggunakan rumus:

$$
\mathrm{PPR}=\frac{\mathrm{n}}{\mathrm{N}} \times 100 \% \text {, dengan }
$$

$\mathrm{n}$, jumlah potongan kayu yang membentuk rizomorf; N, jumlah potongan kayu yang dibenamkan.

\section{Viabilitas dan Pertumbuhan Inokulum}

Viabilitas dihitung sebagai persentase potongan kayu inokulum yang masih membentuk miselium/rizomorf dengan rumus seperti pada perhitungan persentase pembentukan rizomorf. Penghitungan dilakukan saat akhir penelitian (setelah 90 hari pembenaman). Rizomorf dipicu pertumbuhannya selama 15 hari dengan cara seperti saat penyiapan inokulum. Inokulum dinyatakan masih hidup jika terjadi pertumbuhan benang-benang miselium $R$. microporus pada potongan kayu. Rizomorf yang tumbuh diukur panjangnya setiap 3 hari sekali untuk menentukan kecepatan pertumbuhannya. Kecepatan pertumbuhan rizomorf dihitung sebagai koefisien kemiringan dari persamaan hasil analisis regresi linier antara hari pengamatan (sumbu X) dan panjang rizomorf (sumbu Y) pada program Microsoft Excel (Er et al. 2014). Total panjang rizomorf dihitung setelah 15 hari inkubasi dengan menjumlahkan panjang rizomorf dari setiap inokulum yang masih hidup.

\section{Keagresifan Patogen}

Pengujian dilakukan berdasarkan kolonisasi rizomorf dan jumlah nekrosis pada akar tunggang bibit karet. Setelah 90 hari inokulasi dan penanaman tumbuhan terna, bibit dibongkar dan diamati persentase kolonisasi rizomorf pada pangkat batang. Akar tunggang yang mengalami nekrosis bagian pangkal batang dipotong melintang dan dihitung persentase nekrosis akar tunggang (PNA) menggunakan rumus:

$$
\text { PNA }=\frac{\mathrm{n}}{\mathrm{N}} \times 100 \% \text {, dengan }
$$

$\mathrm{n}$, panjang akar tunggang yang melapuk; $\mathrm{N}$, panjang penampang melintang akar tunggang yang diamati (Suwandi 2008). 


\section{Pelapukan Kayu}

Uji pelapukan ini dilakukan pada 90 hari setelah pembenaman. Potongan kayu karet yang digunakan sebagai inokulum $R$. microporus dibongkar dari dalam tanah, dicuci, dikeringkan dalam oven pada suhu $105{ }^{\circ} \mathrm{C}$ selama 24 jam untuk mendapatkan bobot keringnya. Sebelumnya sudah dihitung bobot kering awal kayu inokulum. Bobot kering awal ditaksir dari 30 buah potongan kayu yang dipilih secara acak dari potongan kayu inokulum. Pelapukan potongan kayu dihitung berdasarkan kehilangan bobot kering menggunakan rumus:

$$
\mathrm{P}=1-\left[\frac{\mathrm{BKt90}}{\mathrm{BKt} 0}\right] \times 100, \text { dengan }
$$

P, persentase pelapukan; BKt90, bobot kering potongan kayu setelah 90 hari; BKt0, bobot kering awal (Jasalavich et al. 2000).

\section{Analisis Data}

Data dianalisis dengan sidik ragam dan jika perlakuan berpengaruh nyata $(P<0.05)$ maka dilakukan uji lanjut dengan uji beda nyata terkecil (BNT). Agar asumsi sidik ragam terpenuhi, data persentase pembentukan rizomorf, viabilitas dan pelapukan ditransformasi menggunakan Arcsin. Analisis menggunakan paket program Agricolae and $R c m d r$ pada $R$ statistical software (versi3.3.1;

\section{$R$ Foundation for Statistical Computing, Vienna).}

\section{HASIL}

\section{Pembentukan Rizomorf dalam Tanah}

Perlakuan tumbuhan terna tidak berpengaruh nyata terhadap pembentukan rizomorf dalam tanah pada 45 hari setelah penanaman, tetapi berpengaruh pada 90 hari setelah penanaman. Pembentukan rizomorf R. microporus secara nyata lebih rendah pada perlakuan penanaman garut, temu lawak, lidah mertua, ganyong dan talas (Gambar 1).

\section{Viabilitas dan Pertumbuhan Inokulum}

Perlakuan tumbuhan antagonis berpengaruh nyata dalam menekan viabilitas miselium setelah dibenamkan dalam tanah selama 90 hari. Penekanan viabilitas inokulum terjadi pada seluruh perlakuan tumbuhan terna uji, kecuali lidah mertua (Tabel 1). Miselium yang mengoloni potongan kayu karet menjadi mati sehingga keseluruhan panjang rizomorf menjadi berkurang. Total panjang rizomorf secara nyata lebih rendah pada semua tumbuhan terna uji, kecuali lidah mertua dan nilai terendah ditemukan pada talas dan ganyong (Tabel 1). Namun, perlakuan tumbuhan antagonis tidak memengaruhi kecepatan pertumbuhan (Tabel 1) dan morfologi rizomorf (Gambar 2).

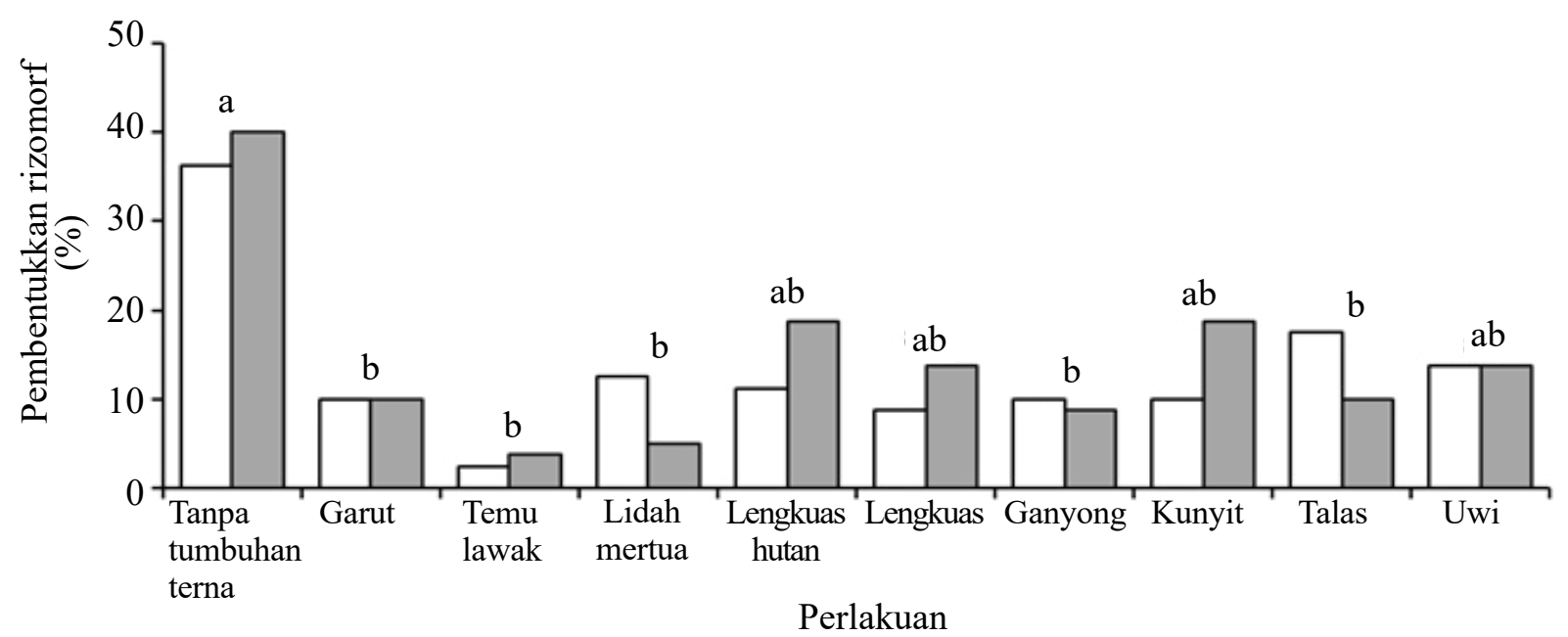

Gambar 1 Pembentukan rizomorf Rigidoporus microporus di dalam tanah yang ditanami tumbuhan terna. Grafik batang yang dilabeli huruf yang sama tidak berbeda nyata berdasarkan uji beda nyata terkecil (BNT) pada $\alpha 5 \%$ dari data yang ditransformasi arcsin. Pembentukan rizomorf setelah 45 hari tidak berbeda nyata pada $\mathrm{P} \geq 0.05$. $\square, 45$ hari setelah pembenaman; $\square, 90$ hari setelah pembenaman. 
Tabel 1 Viabilitas dan pertumbuhan rizomorf Rigidoporus microporus pada potongan kayu karet setelah dibenamkan selama 90 hari di dalam tanah yang ditanami berbagai tumbuhan terna

\begin{tabular}{lccc}
\hline Perlakuan & $\begin{array}{c}\text { Viabilitas } \\
(\%)^{*}\end{array}$ & $\begin{array}{c}\text { Total panjang rizomorf } \\
(\mathrm{mm})\end{array}$ & $\begin{array}{c}\text { Kecepatan tumbuh } \\
(\mathrm{mm} \text { per hari })\end{array}$ \\
\hline Tanpa tumbuhan terna & $70 \mathrm{a}$ & $2620 \mathrm{a}$ & 30.8 \\
Garut & $33 \mathrm{~b}$ & $1207 \mathrm{~cd}$ & 27.9 \\
Temu lawak & $37 \mathrm{~b}$ & $1143 \mathrm{~cd}$ & 26.3 \\
Lidah mertua & $60 \mathrm{a}$ & $2093 \mathrm{ab}$ & 29.1 \\
Lengkuas hutan & $33 \mathrm{~b}$ & $1118 \mathrm{~cd}$ & 28.3 \\
Lengkuas & $33 \mathrm{~b}$ & $1193 \mathrm{~cd}$ & 27.7 \\
Ganyong & $20 \mathrm{~b}$ & $793 \mathrm{~d}$ & 27.9 \\
Kunyit & $23 \mathrm{~b}$ & $902 \mathrm{~cd}$ & 31.3 \\
Talas & $27 \mathrm{~b}$ & $768 \mathrm{~d}$ & 27.9 \\
Uwi & $37 \mathrm{~b}$ & $1575 \mathrm{bc}$ & 33.6 \\
\hline
\end{tabular}

Angka-angka yang diikuti oleh huruf yang sama tidak berbeda nyata berdasarkan uji BNT pada $\alpha 5 \%$.

*Data viabilitas ditransformasi Arcsin

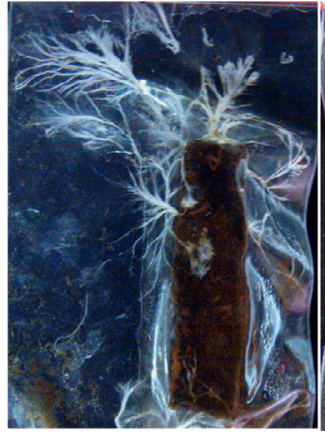

a

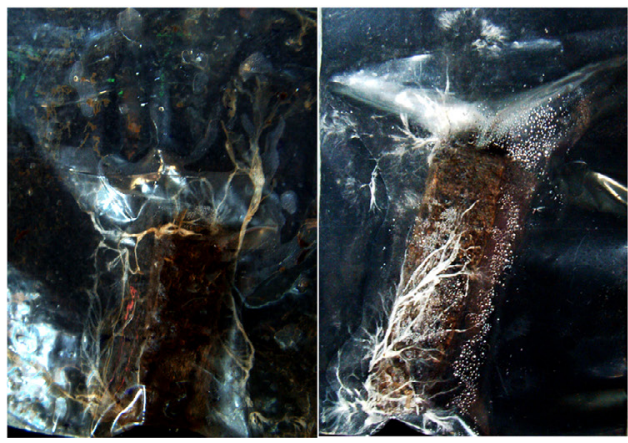

$\mathrm{f}$

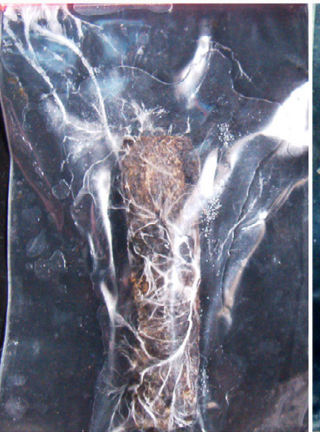

$\mathrm{b}$

g

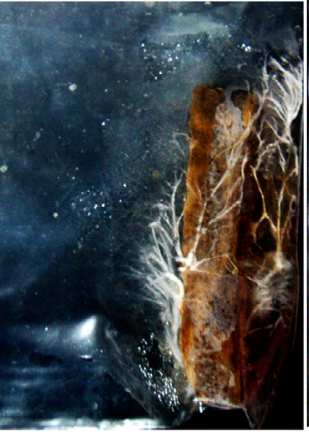

C

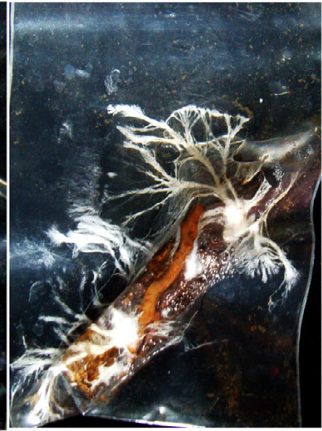

$\mathrm{h}$

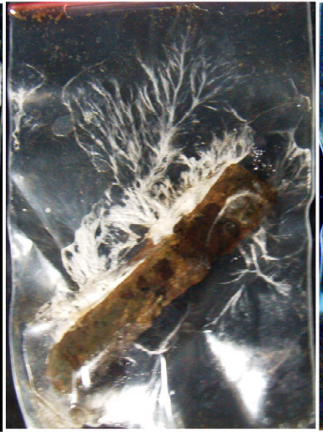

d

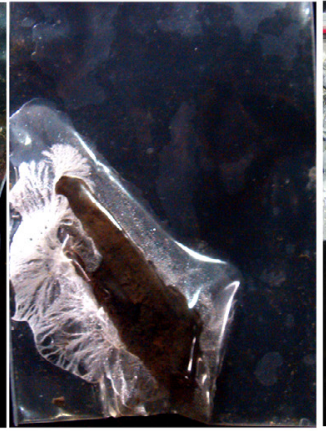

i

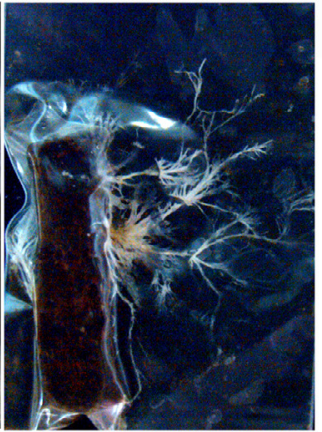

e

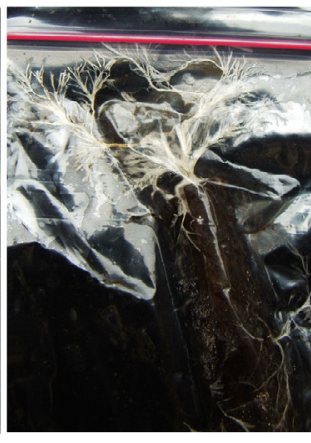

$\mathrm{j}$

Gambar 2 Pertumbuhan rizomorf Rigidoporus microporus dalam kantong plastik berklip dari potongan kayu karet yang telah dibenamkan selama 90 hari dalam tanah yang ditanami tumbuhan terna. a, Tanpa tumbuhan terna; b, Garut; c, Temu lawak; d, Lidah mertua; e, Lengkuas hutan; f, Lengkuas; g, Ganyong; h, Kunyit; i, Talas; dan j, Uwi.

\section{Keagresifan Patogen}

Penanaman tumbuhan terna berpengaruh nyata terhadap keagresifan $R$. microporus saat 90 hari setelah inokulasi. Sampai 90 hari setelah penanaman, tidak ditemukan kolonisasi rizomorf dan nekrosis akar tunggang pada bibit karet pada perlakuan tumbuhan terna, kecuali pada perlakuan lengkuas hutan dan lidah mertua. Nekrosis perlakuan lidah mertua lebih rendah dibandingkan dengan perlakuan tanpa tumbuhan terna (Tabel 2).

\section{Pelapukan Kayu}

Penanaman tumbuhan terna tidak berpengaruh nyata terhadap pelapukan potongan kayu yang digunakan sebagai 
inokulum JAP saat 45 dan 90 hari setelah pembenaman (Tabel 3).

\section{PEMBAHASAN}

Hasil penelitian menunjukkan bahwa semua tumbuhan terna uji memiliki satu atau beberapa aktivitas penekanan potensi inokulum di dalam tanah yang akhirnya dapat mencegah atau menekan infeksi $R$. microporus. Penekanan potensi inokulum oleh tumbuhan terna membuktikan bahwa tumbuhan tersebut dapat bersifat antagonis atau alelopati terhadap miselium $R$. microporus secara in vivo. Ganyong dan talas merupakan terna yang paling efektif menekan potensi inokulum karena menyebabkan rendahnya pembentukan rizomorf dalam tanah, viabilitas inokulum dan total panjang rizomorf $R$. microporus.
Penekanan pembentukan rizomorf oleh ganyong juga ditemukan pada percobaan menggunakan inokulum JAP yang mengoloni cangkang buah karet (Sari 2015). Ganyong dan talas memiliki perakaran yang paling ekstensif dibandingkan dengan terna uji lainnya dan hal ini diduga menyebabkan rizomorf sukar berkembang. Sejauh ini belum dilaporkan aktivitas alelopati akar ganyong dan talas terhadap JAP secara in vitro. Penekanan penyakit akar putih setelah penanaman ganyong dan talas juga belum pernah dilaporkan dan oleh karenanya perlu diteliti lebih lanjut.

Tumbuhan terna uji lainnya, yaitu garut, lidah mertua, temu lawak, lengkuas, dan kunyit telah diketahui dapat bersifat alelopati terhadap miselium $R$. microporus. Situmorang et al. (2007) melaporkan adanya

Tabel 2 Kolonisasi rizomorf Rigidoporus microporus dan nekrosis akar tunggang bibit karet setelah 90 hari inokulasi pada berbagai perlakuan penanaman tumbuhan terna

\begin{tabular}{lcc}
\hline Perlakuan & $\begin{array}{c}\text { Kolonisasi rizomorf } \\
(\%)\end{array}$ & $\begin{array}{c}\text { Nekrosis } \\
(\%)\end{array}$ \\
\hline Tanpa tumbuhan terna & 15.0 & $14.5 \mathrm{a}$ \\
Garut & 0.0 & $0.0 \mathrm{~b}$ \\
Temu lawak & 0.0 & $0.0 \mathrm{~b}$ \\
Lidah mertua & 5.0 & $4.0 \mathrm{~b}$ \\
Lengkuas hutan & 11.9 & $10.8 \mathrm{a}$ \\
Lengkuas & 0.0 & $0.0 \mathrm{~b}$ \\
Ganyong & 0.0 & $0.0 \mathrm{~b}$ \\
Kunyit & 0.0 & $0.0 \mathrm{~b}$ \\
Talas & 0.0 & $0.0 \mathrm{~b}$ \\
Uwi & 0.0 & $0.0 \mathrm{~b}$ \\
\hline
\end{tabular}

Angka-angka yang diikuti oleh huruf yangsama tidak berbeda nyata berdasarkanuji BNT pada $\alpha .5 \%$ dari data yang ditransformasi Arcsin

Tabel 3 Pelapukan kayu karet (\%) yang dikoloni Rigidoporus microporus di dalam tanah yang ditanami berbagai tumbuhan terna

\begin{tabular}{lcc}
\hline \multirow{2}{*}{ Perlakuan } & Pelapukan kayu pada hari ke- ..... setelah pembenaman \\
\cline { 2 - 3 } & 45 & 90 \\
\hline Tanpa tumbuhan terna & 32.9 & 37.8 \\
Garut & 34.7 & 42.4 \\
Temu lawak & 30.8 & 38.0 \\
Lidah mertua & 29.0 & 37.1 \\
Lengkuas hutan & 31.4 & 39.5 \\
Lengkuas & 31.0 & 37.7 \\
Ganyong & 36.0 & 40.4 \\
Kunyit & 37.2 & 41.3 \\
Talas & 33.2 & 39.7 \\
Uwi & 34.9 & 42.8 \\
\hline
\end{tabular}


pengurangan kolonisasi miselium JAP pada potongan kayu karet yang ditempatkan pada eksudat tanaman terna tersebut. Hambatan kolonisasi tertinggi ditemukan pada garut dan lidah mertua. Prasetyo dan Aeny (2013) juga melaporkan adanya hambatan pertumbuhan miselium JAP pada medium agar-agar dekstrosa kentang yang ditambahkan eksudat akar garut dan lidah mertua. Pada penelitian ini lidah mertua menunjukkan aktivitas penekanan pembentukan rizomorf dalam tanah, tetapi tidak dapat menekan viabilitas dan pertumbuhan inokulum yang mengoloni kayu karet. Lidah mertua juga tidak dapat mencegah kolonisasi dan infeksi JAP pada akar karet. Hal ini mengindikasikan bahwa aktivitas antagonis atau alelopati bukanlah satu-satunya mekanisme tumbuhan terna dalam menekan potensi inokulum dan akhirnya mencegah kolonisasi dan infeksi patogen.

Penekanan potensi inokulum JAP oleh tumbuhan terna dapat terjadi melalui aktivitas percepatan pelapukan kayu karet. Situmorang et al. (2007) melaporkan adanya peningkatan pelapukan kayu tunggul karet setelah ditanami dengan tumbuhan terna selama 2 tahun. Seluruh tumbuhan terna dapat meningkatkan pelapukan. Pada penelitian ini tidak ditemukan adanya aktivitas tersebut selama 3 bulan pengujian. Hal ini diduga karena kayu yang diuji menggunakan inokulum yang telah terlebih dahulu dikolonisasi oleh patogen sehingga mikrob pelapuk menjadi kalah berkompetisi.

Hasil penelitian ini menunjukkan manfaat tumbuhan terna sebagai tanaman sela pada budi daya karet. Percobaan lapangan yang dilakukan oleh Situmorang et al. (2007) menunjukkan tumbuhan terna tidak mengganggu pertumbuhan karet. Tidak hanya dapat mencegah dan menekan penyakit, tumbuhan terna dapat bernilai ekologis dan ekonomis. Manfaat garut sebagai tumbuhan sela dalam budi daya karet telah dirasakan selama era 1980-an di Bangka. Pada periode tersebut, garut tumbuh endemis pada kebun karet dan serangan JAP hampir tidak pernah ditemukan. Peranan tumbuhan terna sebagai tanaman sela atau tumpang sari sebanding dengan manfaat sistem agroforestri budi daya karet.

Hasil penelitian ini menunjukkan bahwa tumbuhan terna dapat menghambat secara parsial pembentukan rizomorf dalam tanah, viabilitas inokulum, total panjang rizomorf serta akhirnya dapat mencegah kolonisasi dan infeksi $R$. microporus pada akar tunggang bibit karet. Penekanan potensi inokulum tersebut membuktikan bahwa tumbuhan tersebut dapat bersifat antagonis atau alelopati terhadap miselium $R$. microporus secara in vivo.

\section{DAFTAR PUSTAKA}

Er HL, Hendricks K, Goss EM, Smith M, Schubert TS, Roberts PD, Van Bruggen AHC. 2014. Isolation and biological characterization of Guignardia species from citrus in Florida. J Plant Pathol. 96(1):43-55.

Fairuzah Z, Dalimunthe CI, Karyudi, Suryaman S, Widhayati W. 2014. Keefektifan beberapa fungi antagonis (Trichoderma sp.) dalam biofungisida endohevea terhadap penyakit jamur akar putih (Rigidoporus microporus) di lapangan. J Penelitian Karet. 32(2):122128. DOI: https://doi.org/10.22302/jpk. v32i2.158.

Fox RA. 1977. The impact of ecological, cultural and biological factors on the strategy and cost of controlling root disease in tropical plantation crops as exemplified by Hevea brasiliensis. J Rubb Res Inst Sri Lanka. 54(2):329-362.

Hashim I, Malik A. 2007. Research on white root disease of hevea rubber: achievements and future direction. Di dalam: Proceedings Internasional Workshop on White Root Disease of Hevea Rubber; 2006 Nov 28-29; Salatiga (ID): Indonesian Rubber Research Institute. hlm 127-137.

Jasalavich CA, Ostrofsky A, Jellison J. 2000. Detection and identification of decay fungi in spruce wood by restriction fragment length polymorphism analysis of amplified genes encoding rRNA. App Environ Microbiol Maine. 66(1):4725-4733. DOI: 
https://doi.org/10.1128/AEM.66.11.47254734.2000.

Kusdiana APJ, Munir M, Suryaningtyas H. 2015. Pengujian biofungisida berbasis mikroorganisme antagonis untuk pengendalian penyakit jamur akar putih pada tanaman karet. J Penelitian Karet. 33(2):143-156. DOI: https://doi. org/10.22302/jpk.v33i2.179.

Liyanage NIS, Peries OS, Liyanage AdeS, Warnapura SS. 1980. Studies on the spread of white root disease caused by Rigidoporus lignosus in Sri Lanka. J Rubber Res Ins Sri Lanka. 57:26-36.

Natawijaya H. 2007. Government policy on the control of white root disease Rigidoporus. Di dalam: Proceedings Internasional Workshop on White Root Disease of Hevea Rubber; 2006 Nov 28-29; Salatiga (ID): Indonesian Rubber Research Institute. hlm 3-13.

Prasetyo J, Aeny TN. 2013. The preventive control of white root rot disease in small holder rubber plantation using botanical, biological and chemical agents. J HPT Tropika.13(1):69-74.
Sari A. 2015. Efektivitas tanaman antagonis dalam menekan perkembangan inokulum jamur akar putih (Rigidoporus microporus) [skripsi]. Indralaya (ID): Universitas Sriwijaya.

Semangun H. 2007. White root disease of rubber: Some of its biological aspects. Di dalam: Proceedings Internasional Workshop on White Root Disease of Hevea Rubber; 2006 Nov 28-29; Salatiga (ID): Indonesian Rubber Research Institute. hlm 60-67.

Situmorang A, Suryaningtyas H, Febbianti TR. 2007. The control of white root disease using antagonistic plant on rubber plantation. Di dalam: Proceedings Internasional Workshop on White Root Disease of Hevea Rubber; 2006 Nov 28-29; Salatiga(ID): Indonesian Rubber Research Institute. hlm 82-86.

Suwandi. 2008. Evaluasi kombinasi isolat Trichoderma mikroparasit dalam mengendalikan penyakit akar putih pada bibit karet. JHPT Tropika. 8(1):55-62. 